\title{
ПРОПОЗИЦІЇ ЩОДО ВИЗНАЧЕННЯ ТАКТИКИ БОЙОВОГО ЗАСТОСУВАННЯ РАКЕТНИХ КАТЕРІВ У ЧОРНОМУ ТА АЗОВСЬКОМУ МОРЯХ
}

В статті розроблені пропозищї щуодо визначення тактики бойового застосування ракетних катерів у Чорному та Азовському морях.

Ключові слова: ракетний катер, морська иіль, ракетна зброя, морський бій, ракетний удар, бойове застосування, протикорабельна крилата ракета.

\section{Вступ}

Постановка проблеми. Аналіз останніх локальних війн та військових конфліктів на морі показує, що кораблі та катери з ракетною зброєю мають велике значення для досягнення загальної перемоги над противником.

Військово-політична обстановка в регіоні Чорного та Азовського морів сьогодні характеризується тим, що Російська Федерація прагне до того, щоб вона, всупереч нормам міжнародного права, мала повний контроль в цьому регіоні, а Азовське море стало їх “великим” озером.

Це обумовлюється наступним:

- збільшення чисельності морського компоненту збройних сил РФ в регіоні;

- збільшення чисельності авіаційного та сухопутного компоненту ЗС РФ у регіоні;

- відверто агресивні заяви окремих радикальних політиків РФ щодо можливої війни з Україною;

- підвищення розвідувально-диверсійної активності в регіоні;

- регулярні порушення норм міжнародного морського права щодо цивільного судноплавства, користування міжнародними водами в Чорному та Азовському морі ВМФ РФ та прикордонними силами (ФСБ РФ).

Аналіз особливостей театру бойових дій, обороноспроможності ВМС України сьогодні щодо протидії можливому агресору 3 моря та важливе економічне значення Чорного та Азовського морів для нашої держави доводять, що саме 3 цього напрямку, імовірний противник може досягнути найбільших стратегічних успіхів.

Аналіз останніх досліджень і публікацій наукової літератури та існуючих нормативних документів показує, що при веденні бойових дій ракетними кораблями, існує багато способів ведення бойових дій, але вони не в повній мірі відповідають оперативній обстановці в регіоні та особливостям району бойових дій біля берегів України.
Тому, метою статті є визначення тактики бойового застосування перспективної ракетної зброї катерами ВМС України при імовірній агресії з боку РФ у Чорному морі.

\section{Виклад основного матеріалу}

Ракетні кораблі (катери) - це ударна зброя сучасних військово-морських сил, найбільша ефективність якої проявляється в операціях з оборони власного узбережжя та територіальних вод в зоні можливого виконання завдань [1].

Зважаючи на багатократну перевагу потенціального противника (ЧФ РФ) в чисельності та бойовій потужності корабельної складової, авіації (в тому числі морської) 3 великою долею імовірності можна передбачити, що в разі збройного конфлікту, ним буде встановлений режим глобального контролю над більшою частиною ЧорноморськоАзовського регіону, як на морі, так і в повітрі.

Тому, бойові зіткнення у відкритому морі практично виключаються, оскільки не мають ніяких тактичних перспектив. Основні дії наших сил повинні бути спрямовані на оборону територіального моря та лінії власного узбережжя. Зоною оборонних дій ВМС імовірно може стати прибережна смуга шириною до 20 морських миль, а також акваторія в районі острова Зміїний.

Північно-західна частина Чорного моря характеризується наявністю великої кількості мілководних лиманів, заток, гирл річок, тощо, закритих косами, піщаними відмілинами, районами, малопридатними для плавання (Одеська, Дністровська банки, Березанський, Дніпровський та Дністровський лимани, Тендрівська, Кінбурнська, Джарилгацька коси та затоки, гирла Дунаю та інші).

Таким чином, ракетні катери, які мають на озброєнні протикорабельні ракети (в тому числі ПКР “Нептун”), мають великий бойовий потенціал щодо відбиття атак імовірного морського противника у Чорному та Азовському морях. Але, нажаль, кількість їх у складі Військово-Морських Сил недо- 
статня для відсічі повномасштабної агресії у морі.

Так, у складі ВМС України мається ракетний катер проекту 206МР “Прилуки”, який у перспективі може бути озброєний протикорабельними ракетами "Нептун". Також, згідно меморандуму, підписаному з Великою Британією, у найближчій перспективі планується побудова та прийняття на озброєння нових ракетних катерів з протикорабельними ракетами.

Ракетний катер проекту 206МР призначений для ураження бойових кораблів, транспортів і десантних засобів противника в морі та місцях їх базування в ближній морській зоні. Катер має гладкопалубний сталевий корпус з носовим мало зануреним крилом. Корпус розділяється на десять відсіків дев'ятьма водонепроникними переборками. Корпусу в надводній частині була надана незвичайна форма: для поліпшення умов змиву палуби при радіоактивному забрудненні стик палуби з бортом спеціально закруглений. Надбудови зроблені з легких сплавів.

Морехідні якості катеру забезпечують можливість його використання без обмежень по швидкості при хвилюванні моря до 4 балів включно і на швидкостях до 30 вузлів при хвилюванні моря 5 балів.

Тактико-технічні характеристики катеру проекту $-206 \mathrm{MP}$.

Водотонажність:

$$
\begin{aligned}
& -232.4 \text { т (стандартна). } \\
& -245.3 \text { т (нормальна). } \\
& -258.2 \text { т (повна). }
\end{aligned}
$$

Довжина: 39.5 м.

Ширина: 7.6 м.

Осадка: 3,25 м.

Швидкість ходу:

- 42 вузла (найбільша).

- 14 вузлів (економічна).

Дальність плавання:

- 490 миль (36 вузлів).

- 930 миль (12 вузлів).

Автономність: 5 діб.

Екіпаж: 29 чол.

Морехідність: до 5 балів (по застосуванню керованої ракетної зброї).

3 метою забезпечення прихованості дій та раптовості нанесення ракетного удару по противнику, доцільно передбачити для таких кораблів (катерів) зовнішні джерела цілевказівки (берегові, корабельні, дані розвідки інших видів 3С України).

Важливим завданням при цьому буде забезпечення захищеної та стійкої системи управління та зв'язку, яку необхідно створювати вже зараз. Протиповітряна оборона кораблів (катерів) в прибережній зоні може бути забезпечена береговими засобами та винищувальною авіацією Повітряних Сил на глибину до 30-40 км від лінії узбережжя [2].

Близькість до своїх баз та пунктів базування, обладнання додаткових окремих берегових пунктів постачання (в тому числі мобільних) в районі дає можливість оперативно поповнювати матеріальнотехнічні запаси та боєкомплект.

На озброєнні збройних сил РФ знаходяться засоби космічної та повітряної розвідки, які спроможні виявляти морські цілі $з$ високою імовірністю та передавати інформацію по них на вогневі засоби в реальному масштабі часу.

До них можна віднести літаки дальнього радіолокаційного виявлення та управління А-50У, перспективний А-100.

Імовірність викриття своїх сил, очевидно залежить від демаскуючих ознак самих кораблів (катерів) та їх ордерів. Демаскуючі ознаки - це властивості та якості, які притаманні кораблям (катерам), по яких здійснюється їх виявлення (викриття).

Аналіз демаскуючих ознак щодо виявлення кораблів (катерів) дозволяє визначити шляхи їх зменшення $з$ метою покращення їх бойової стійкості.

До демаскуючих ознак кораблів (катерів) різних класів та їх ордерів відносяться наступні:

- побудова кораблів (катерів);

- елементи надводної частини корабля (катера);

- контури кораблів (катерів) різного класу;

- розміри кораблів (катерів) різного класу;

- особливості розміщення елементів надводної частини корабля (катеру) різного класу;

- колір кораблів (катерів), якщо він відрізняється від місцевості;

- ознаки діяльності - електромагнітне та інфрачервоне випромінювання, характерні звуки, спалахи вогню, дим та інші;

- склад ордерів кораблів (катерів) та їх розміщення в ньому, характерні відстані між кораблями (катерами);

- швидкість руху кораблів (катерів) на переході морем.

Імовірність виявлення кораблів (катерів) $P_{\text {виявл }}$ залежить від ряду факторів, основними з яких є:

- час ведення розвідки $j$-м засобом розвідки $t_{\text {розв }_{j}}$;

- щільність розвідувальних ознак (демаскуючих факторів) кораблів (катерів) $j$-му засобу розвідки (кількість ознак за одиницю часу) $-\mu_{j}$;

- середньостатистична імовірність виявлення розвідувальних ознак $j$-м засобом розвідки $-P_{b_{j}}$.

За основу розрахунку імовірності розвідування кораблів (катерів) розвідкою противника може бути використана теорія пошуку об'єктів, яка приведена y [4].

У цьому випадку, імовірність виявлення кораблів (катерів) у пунктах базування та при переході 
морем $P_{\text {виявл }}$ може визначатися за формулою [3]:

$$
P_{\text {виявл }}=\exp \left(-\sum_{j} \mu_{j} t_{\text {розв }} P_{\beta_{j}}\right) .
$$

3 метою введення противника в оману, забезпечення високої бойової стійкості кораблів (катерів) можуть визначатися та облаштовуватися оманні кораблі (катери) та їх позиції. При цьому, очевидно, що імовірність прийняття $k$-го оманного корабля (катера) за істинний залежить від їі правдоподібності - $\gamma_{k}$, тому, можна записати [3]:

$$
P_{\text {виявл }}=\frac{\exp \left(-\sum_{j} \mu_{j} t_{\text {розв }} P_{{ }^{\prime}}\right)}{1+\gamma_{k}},
$$

де $k$ - кількість оманних кораблів (катерів) для одного істинного;

$\gamma$ - імовірність прийняття $k$-го оманного корабля (катера) за істинний;

Значення $\gamma$ може змінюватися від 0 до 1 (при $\gamma=1$ оманний корабель або катер повністю відповідає істинному кораблю або катеру).

Час ведення повітряної або космічної розвідки залежить від часу знаходження носія розвідки у районі базування кораблів (катерів) або переходу морем та від технічних характеристик засобу розвідки.

Наприклад, час ведення космічної радіолокаційної розвідки кораблів (катерів) розвідувальним супутником серії “Лакрос", який знаходиться на геостаціонарній орбіті, рівний часу знаходження супутника на орбіті.

Щільність розвідувальних ознак (демаскуючих факторів) кораблів (катерів) залежить від кількості їх розвідувальних ознак (демаскуючих факторів), які можуть бути проявлені за певний час розвідки.

Для кораблів (катерів) щільність цих ознак достатньо велика тому, що вони мають в залежності від проекту характерні конфігурацію, побудову, розміри, кількість надводних елементів, ознаки діяльності, види ордерів та швидкості на переході морем.

За даних умов та при існуючих характеристиках сучасних та перспективних засобів космічної і повітряної розвідки провідних держав світу приховати кораблі (катери) в пунктах базування та на переході їх морем у складі ордерів сьогодні та й у найближчій перспективі практично не можливо.

Тому, для зменшення імовірності викриття (розвідування) кораблів (катерів) $P_{\text {виявл }}$ необхідно мати багато оманних правдоподібних кораблів (катерів). Для цього необхідні великі фінансові та матеріальні витрати, що сьогодні та у найближчій перспе- ктиві, в умовах ресурсних обмежень держави, стає дуже проблематичним. Інакше, імовірність виявлення кораблів (катерів) існуючими та перспективними засобами розвідки в пунктах базування та при переході їх морем стає близько до 1.

Але, бойова стійкість кораблів (катерів) залежить не тільки від їх виявлення. Очевидно, вона залежить також і від імовірності ураження зброєю противника $P_{\text {ураж }}$ (наприклад, імовірності ураження корабля (катеру) однією протикорабельною ракетою).

Тому, припускаючи, що виявлення кораблів (катерів) та нанесення по них ударів засобами ураження являються незалежними подіями, можна ввести поняття коефіцієнту бойової стійкості, який можна розраховувати за формулою:

$$
K_{\text {бс }}=P_{\text {виявл }} \cdot P_{\text {ураж }} .
$$

3 метою оцінки (розрахунку) реальних бойових можливостей кораблів (катерів) ВМС України та їх угруповань, цей коефіцієнт пропонується враховувати в існуючих методиках розрахунку бойових можливостей.

Таким чином, сьогодні необхідно шукати нові або удосконалювати існуючі способи бойових дій ракетними катерами у Чорному та Азовському морях з метою забезпечення їх високої бойової стійкості та ефективної протидії можливої агресії РФ у цьому регіоні. При цьому, необхідно забезпечити високу бойову стійкість ракетних катерів, яка, в свою чергу залежить від імовірності їх виявлення засобами розвідки противника. Тобто, нові (удосконалені) способи бойових дій повинні забезпечити скритність, рішучість та оперативність бойових дій ракетними катерами.

Цього можна досягти при раптових для противника бойових пусків протикорабельних ракет ракетних катерів із прихованих вогневих позицій. Ця тактика бойових дій називається тактикою дій ракетних катерів “із засідки”, тобто, спосіб бойових дій “із засідки”. При цьому способі бойових дій повинно бути передбачене негайне залишення вогневої позиції після пуску ракет і перехід на іншу вогневу позицію.

Спосіб бойових дій “із засідки”- - це спосіб дій, при якому ракетні катери (їх тактичні групи) розташовуються на шляхах руху противника, а потім раптово виходять на бойові позиції та здійснюють ракетний залп по ньому.

В залежності від об'єктивності та оперативності інформації про противника, засідки можуть бути підготовленими або миттєвими (відразу).

Підготовлена засідка - результат хорошої розвідки противника і маршрутів його пересування. Це запланований спеціальний захід на заздалегідь відо- 
мому або передбачуваному маршруті руху противника. Підготовлена засідка потребує ретельного планування та всебічного забезпечення.

Миттєва засідка - це спосіб дій при різкій зміні обстановки в майбутньому районі бойових дій ракетними катерами.

При вмілому плануванні та грамотному проведенні засідки навіть малочисельна тактична група ракетних катерів може завдати противнику значних втрат, при яких він відмовиться від виконання поставлених завдань.

Тобто, спосіб дії із засідки може стати найкращим і максимально ефективним способом боротьби ракетними та артилерійськими катерами ВМС України 3 морським противником при здійсненні ним агресії у Чорному морі з південного напрямку.

При проведенні засідки бойовий порядок групи може складатися 3 наступних підгруп:

- вогнева підгрупа - для знищення противника протикорабельними ракетами або вогнем артилеріі;

- підгрупа розвідки - для виявлення противника та передачі цілевказівки по ньому на ударні засо- би катерів;

- оманна підгрупа - для введення противника в оману відносно основних ударних сил.

Основним завданням засідки є нанесення противнику максимального ураження протягом перших секунд бою, перш ніж він зможе надати організовану вогневу протидію.

Вибір місця проведення засідки і маршруту виходу до неї повинен здійснюватися при завчасній підготовці бойових дій по карті. Він повинен уточнюватися на етапі безпосередньої підготовки бойових дій при виході до місця проведення засідки.

\section{Висновки}

Запропоновано новий спосіб ведення бойових дій ракетними катерами в Чорному та Азовському морях “із засідки”, який дозволить набагато підвищити їх бойову стійкість, забезпечить ефективне знищення надводних сил військово-морських сил РФ у випадку їх можливої агресії.

\section{Список літератури}

1. Родионов И. М. Военная энциклопедия. Москва : Военное издательство, 1994. Т. 1. 328 с.

2. Срмошин М. О., Федай В. М. Боротьба в повітрі. Харків : ХВУ, 2004. 381 с.

3. Абчук В. А., Суздаль В. Г. Поиск объектов. Москва : Сов. радио. 1977. 336 с.

4. Риженко А. О. Стан, перспективи розвитку та завдання Військово-Морських Сил. Проблемні питання та шляхи їх вирішення. Морська стратегія держави. Розвиток та реалізація морського потенціалу України : матеріали міжн. наук. форуму, 24-25 травня 2016 р. Київ : НУОУ ім. І. Черняховського, 2016. С. 76-84.

5. Яким’як С. В. Морська стратегія України. Оборонний вісник. 2016. № 5. С. 28-32.

6. Кабаненко І. В. Корабельні спроможності ВМС ЗС України: розумний підхід. Морська стратегія держави. Розвиток та реалізація морського потенціалу Украӥни : матеріали міжнар. наук. форуму, 24-25 травня 2016 р. Київ : НУОУ ім. І. Черняховського, 2016. С. 40-44. № $1(2)$.

7. Экзетер. Боевые действия на море в ходе арабо-израильской войны 1973 г. Войны. История, Факты. 2002.

8. Доценко В. История военно-морского искусства. Санкт-Петербург : Эксмо, 2005.

9. ВМС Грузии. Руссфлот : веб-сайт. URL: http://russ-flot.narod.ru/SNG_gruzia/htm (дата звернення: 01.11.21).

10. Заболотный А. Британские вертолеты в Фолклендской войне. Авиациия и время. 1999. № 4. С. 36.

11. Birth, Death, and Rebirth of the Iraqi Navy. Covertshores : веб-сайт. URL: http://covertshores.blogspot.com/2010/10/birth-death-and-rebirth-of-iraqi-navy.html (дата звернення: 01.11.21).

12. Операция “Богомол” - крупнейшее морское сражение после Фолклендов. Альтернативная история : веб-сайт. URL: http://alternathistory.com/operatsiya-bogomol-krupnejshee-morskoe-srazhenie-posle-folklendov/ (дата звернення: 01.11.21).

\section{Відомості про авторів:}

Харитонов Олександр Леонідович кандидат військових наук доцент Національного університету

"Одеська морська академія",

Одеса, Україна

https://orcid.org/0000-0002-7285-8001

\section{Завгородній Денис Сергійович}

кандидат педагогічних наук

доцент Національного університету

“Одеська морська академія",

Одеса, Україна

https://orcid.org/0000-0003-3244-9163
Information about the authors:

Oleksandr Kharytonov

$\mathrm{PhD}$ in Military Science

Senior Lecturer of the National University

"Odessa Maritime Academy",

Odessa, Ukraine

https://orcid.org/0000-0002-7285-8001

\section{Denys Zavhorodnii}

$\mathrm{PhD}$ in Pedagogical Science

Associate Professor of the National University

"Odessa Maritime Academy",

Odessa, Ukraine

https://orcid.org/0000-0003-3244-9163 


\section{ПРЕДЛОЖЕНИЯ ПО СОВЕРШЕНСТВОВАНИЮ ТАКТИКИ БОЕВОГО ПРИМЕНЕНИЯ} РАКЕТНЫХ КАТЕРОВ В ЧЕРНОМ И АЗОВСКОМ МОРЯХ

\section{О.Л. Харитонов, Д.С. Завгородний}

В статье разработаны предложения по усовершенствованию тактики боевого применения ракетных катеров 6 Черном и Азовском морях.

Ключевые слова: ракетный катер, морская цель, ракетное оружие, морской бой, ракетный удар, боевое применение, противокорабельная крылатая ракета.

\section{SUBSTANTIATION AND RECOMMENDATIONS FOR IMPROVING TACTICS OF APPLICATION OF ROCKET BOATS BOATS IN THE BLACK AND AZOV SEAS}

O. Kharytonov, D. Zavhorodnii

This article analyzes and substantiates the urgency of the problem of using missile weapons by promising naval carriers of the Ukrainian Navy (boats, small missile ships) for naval purposes in modern conditions. Appearing in the late 1950s, ships (boats) with missile weapons today have become an integral part of the navies of most maritime nations. The first combat application showed that the new weapon radically changed the tactics and views of naval combat. A new direction of tactical thought was initiated, which was later transferred to other types of forces. The concept of naval combat has lost its traditional meaning, inherent in the birth of war at sea. The offensive potential of the missile carrier is much higher than the defensive one, especially for small missile ships (boats). The classic naval battle, as the impact on the enemy with weapons and at the same time the defense against his influence, when establishing eye contact, became irrational, it began to be avoided. The main method of application was a missile strike - the use of missile weapons without entering the enemy's counter-zone. Analysis of the peculiarities of a possible theater of operations, namely the relatively low defense capability of Ukraine to counter the threat from the sea and the important economic importance of the Black and Azov Seas for Ukraine prove that in this direction, the aggressor can achieve the greatest strategic success. Therefore, the development of tactics, methods of using promising missile weapons of the Ukrainian Navy, evaluation (preliminary calculation) of the effectiveness of its use, increasing such efficiency are the key tasks of military (naval) science today. Given the multiple advantage of the potential enemy (Black Sea Fleet) in the number and combat power of the ship's component, aviation (including naval) with a high probability it is possible to predict that in case of armed conflict, it will establish a regime of global control over most of the Black Sea-Azov region, both at sea and in the air. Therefore, combat clashes on the high seas are virtually ruled out, as they have no tactical prospects. The main actions of our forces will be aimed at defending the territorial sea and the lines of our own coast. The Navy's area of defense is likely to be a coastal strip up to 20 nautical miles wide, as well as the area around Snake Island. In the north-western part of the Black Sea coast of Ukraine is characterized by the presence of a large number of shallow estuaries, bays, estuaries, etc., closed by spit, sandy shoals, areas unsuitable for navigation (Odessa, Dniester banks, Dnieper and Dniester estuaries, Tendrivskaya, Kinburtskaya bays, the mouth of the Danube and others). Such conditions favor the actions of small missile ships (boats), using "ambush" tactics. Using shallow water, coastal background (mostly depths of 3-20 m), its own low radar visibility, using comprehensive camouflage measures (visual and radio engineering), such RCC carriers can covertly occupy and change firing positions due to natural obstacles, which significantly reduces the likelihood of their detection. and enemy intelligence. Thus, the article proposes a new way of fighting missile boats in the Black and Azov Seas "from ambush", which will greatly increase their combat resilience, will ensure the effective destruction of surface forces of the Russian Navy in case of possible aggression.

Keywords: missile boat, naval target, missile weapon, sea battle, missile strike, combat use, anti-ship cruise missile. 